

Moolphuerk N and Pattanagul W (2020)

Notulae Botanicae Horti Agrobotanici Cluj-Napoca 48(4):2072-2084

DOI: $10.15835 / 48412018$

Research Article

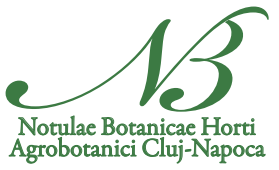

\title{
Pretreatment with different molecular weight chitosans encourages drought tolerance in rice (Oryza sativa L.) seedling
}

\author{
Namphueng MOOLPHUERK, Wattana PATTANAGUL*
}

Khon Kaen University, Faculty of Science, Department of Biology, 123 Moo 16 Mittraphap Rd., Nai-Muang, Muang District,

Khon Kaen40002, Thailand; Namphueng_moolphuerk@kkumail.com; wattana@biology.in.th (*correspondingauthor)

\begin{abstract}
Drought is a critical environmental constraint limiting plant growth and productivity. Chitosan has been utilized as a potential biostimulant and proven to be effective against drought stress in many plant species. The objective of this study was to determine the effects of pretreatment with different molecular weight (MW) chitosans on some physiological characteristics of rice seedlings under drought stress. Rice seedlings were treated with low (50-190 kDa), medium (190-310 kDa) and high (310-375 kDa) MW chitosans by seed priming and foliar spray. The seedlings were subjected to drought by withholding water for four days. The relative water content (RWC) was reduced from $93 \%$ in the control plants to $74 \%$ in the droughted plants. The results revealed that treating with chitosan, especially with low MW chitosan, promoted root growth under drought stress. All chitosan treatments led to higher relative water content and photosynthetic pigment under drought condition. Pretreatment with chitosan also induced sugar accumulation, and treating with low MW chitosan significantly increased starch accumulation under drought stress. In addition, chitosan treatments alleviated the effects caused by drought stress as represented by the decreases in electrolyte leakage, malondialdehyde (MDA) as well as hydrogen peroxide $\left(\mathrm{H}_{2} \mathrm{O}_{2}\right)$, corresponding with the increases in activities of antioxidant enzymes superoxide dismutase (SOD), catalase (CAT), ascorbate peroxidase (APX), and guaiacol peroxidase (GPX) activity.
\end{abstract}

Keywords: antioxidant enzymes; chitosan; drought stress; foliar application; rice; seed priming

\section{Introduction}

The ongoing increase of the severity and frequency of drought in a warming climate negatively affects agricultural production and threaten food security worldwide. Drought stress is one of the critical limiting factors affecting both the quality and quantity of many agricultural products, especially rice. Thailand is one of the world's largest producer and exporter of rice, but current rice production is still limited by rainfall variability and drought due to the most of farmers' popular and famous rice varieties are susceptible to drought stress. Among these varieties, 'Khao Dawk Mali 105' ('KDML105') is famous in either the country or worldwide. Demand for this variety is increasing in both domestic and international markets; however, the cultivation is limited by infertile and drought soil (Yoshihashi et al., 2004). The 'KDML105' rice is mainly cropped in Northeastern Thailand, the highest quality rice production area. Approximately $90 \%$ of rice cultivation in 
northeast Thailand is rain-fed, therefore rainfed rice yields in this region are generally below potential due to water shortages (Prabnakorn et al., 2018).

Drought stress limits plant growth by reducing cellular turgor pressure as well as limiting photosynthesis due to stomatal closure. Drought stress also induces free radicals and reactive oxygen species (ROS) causing damage to various cellular components. Accumulation of ROS results in the loss of membrane stability and integrity along with the reduction of photosynthetic pigments such as chlorophylls. Naturally, plants display a range of mechanisms to withstand drought stress; however, these mechanisms vary between plant species (Toldi et al., 2009). In the case of the drought-susceptible plants, these mechanisms are not sufficient to overcome water deficit or drought conditions (Fang and Xiong, 2015). Various management strategies have been proposed to cope with drought stress. Among these, plant biostimulants received considerable attention during the past few years due to their efficiency to enhance abiotic stress tolerance and improve plant productivity (Du Jardin, 2015). Plant biostimulants include diverse formulations of compounds, substances, and other products that are applied to plants or soils to regulate and enhance the crop's physiological processes, thus making them more efficient (Sharma et al., 2014). There are several classes of plant biostimulants, but chitosan has been proven to be effective in term of improving abiotic stresses.

Chitosan is a natural polymer and one of the chitin derivatives when the degree of deacetylation of chitin reaches about 50\% (Rinaudo, 2006). Chitosan is obtained after deacetylation of chitin in which its chemical structure composed of a linear polymer consisting of two subunits, D-glucosamine and $N$-acetyl-Dglucosamine linked together by glycosidic bond (Hidangmayum et al., 2019). The functional properties of chitosan such as solubility, biodegradability, and diverse bioactive attributes are related to molecular weight and the degree of deacetylation (Rajoka et al., 2019). Many studies have differently determined classes of chitosan based on its molecular weight; however, the specific categories are still unclear. Commercially, chitosan is classified into three main different classes: low $(50-190 \mathrm{kDa})$, medium $(190-310 \mathrm{kDa})$, and high (310-375 kDa) molecular weight (MW) (Prashanth and Tharanathan, 2007). The cationic nature of chitosan is somewhat unique because most of the polysaccharides are usually either neutral or negatively charged in an acidic condition. The unique property allows it to generate electrostatic complexes with other negatively charged synthetic or natural polymers (Rinaudo, 2006). Chitosan has been, therefore, investigated and developed as a plant biostimulant (Katiyar et al., 2015; Hidangmayum et al., 2019). In plants, chitosan elicits numerous defense responses related to biotic and abiotic stresses. It has been utilized effectively in many plantrelated applications to increase plant productivity as well as protect plants against the attack of pathogens (Malerba and Cerana, 2018). Previous studies revealed that chitosan has a potential to enhance plant growth as well as increase yield in many crops including apple, wheat, maize and rice (Yang et al., 2009; LizárragaPaulín et al., 2011; Zeng and Luo, 2012; Seang-Ngam et al., 2014). In drought stress, chitosan treatment alleviates the adverse effect of drought stress by increasing antioxidant enzyme activities, promoting root water absorption capability by increasing root growth and enhancing photosynthetic activities. It has been suggested that chitosan binds specific receptors located in plant cell membranes, which triggers signal transduction cascade via various secondary messengers, including ROS, hydrogen peroxide $\left(\mathrm{H}_{2} \mathrm{O}_{2}\right)$, nitric oxide, and phytohormones. $\mathrm{H}_{2} \mathrm{O}_{2}$ leads to abscisic acid production and induces $\mathrm{ROS}$ scavenging mechanism, while nitric oxide initiates ABA synthesis leading to stomatal closure as well as triggering stress-responsive genes (Hidangmayum et al., 2019). Nevertheless, it was reported that different molecular weight chitosan exhibit different level of protein and compound, suggesting chitosan have varied functionality depending upon its class (Lin et al., 2005).

Due to the ongoing and severity of drought stress in Thailand, it is essential to find a solution to mitigate the problem and improve the quality of rice production. Plant biostimulants, chitosan in particular, have received much attention in the research related to abiotic stress. Although chitosan has been proven to be effective in promoting stress tolerance in plants, relationships between MW and biological properties as well as its mechanism remain unclear. Our research aims to investigate the effects of pretreatment with different $\mathrm{MW}$ chitosans on drought tolerant in the 'KDML105' rice seedlings. Three classes of chitosan, including low, 
medium, and high MW chitosan, were used in our experiment. Growth parameters, including root and shoot lengths, root and shoot fresh and dry weights, were determined. In addition, some physiological characteristics related to drought tolerant response, such as relative water content, chlorophyll content, electrolyte leakage, malondialdehyde (MDA) concentration, total soluble sugar and starch content as well as antioxidant enzyme activities were examined.

\section{Materials and Methods}

\section{Chitosan solution preparation}

Three types of commercial chitosan including low MW (50-190 kDa with 20-300 cP viscosity), medium MW (190-310 kDa with 200-800 cP viscosity) and high MW (310-375 $\mathrm{kDa}$ with 800-2000 cP viscosity) with 75-85\% deacetylation was purchased from Sigma-Aldrich (Saint Louis, MO, USA). Chitosan solution for seed priming, five mg of chitosan powder was entirely dissolved in $2 \mathrm{ml}$ of $1 \%$ acetic acid, $98 \mathrm{ml}$ of distilled water was then added to obtain $100 \mathrm{ml}$ of $50 \mathrm{mgl}^{-1}$ chitosan solution, the solution was adjusted to $\mathrm{pH} 6.0$ using $1 \mathrm{M}$ $\mathrm{NaOH}$. Acidified distilled water used in no-chitosan treatment was prepared by the combination of $2 \mathrm{ml}$ of $1 \%$ acetic acid and $98 \mathrm{ml}$ of distilled water then the $\mathrm{pH}$ of the solution was adjusted to 6.0 by using $1 \mathrm{M} \mathrm{NaOH}$. Chitosan solution, $200 \mathrm{ml}$ of $50 \mathrm{mgl}^{-1}$, and acidified water for foliar spray were prepared using the same method as mentioned above and Tween 20 (Sigma-Aldrich, Saint Louis, MO, USA) was added as leaf surfactant in foliar application.

\section{Plant material and experimental design}

Rice seeds (Oryza sativa L.) cv. 'KDML105 obtained from Khon Kaen Rice Research Center, Khon Kaen, Thailand were surface sterilized by soaking in $80 \%$ ethanol for 30 seconds followed by soaking in $3 \%$ sodium hypochlorite solution for $10 \mathrm{~min}$ and washing with sterile distilled water for $10 \mathrm{~min}$ three times. The experiment which was divided into five treatments with four replicates was consisted of control (no drought and no chitosan treatment), drought (withholding water and no chitosan treatment), low, medium, and high MW chitosan (withholding water and chitosan-treated treatment). For control and drought treatments, sterilized seeds were primed in acidified water, meanwhile chitosan treatments seeds were primed in chitosan solutions for $48 \mathrm{~h}$. Seven seeds were implanted in a plastic pot $(20.32 \mathrm{~cm}$ in diameters and $17.78 \mathrm{~cm}$ in height) filled with $2 \mathrm{~kg}$ of paddy soil obtained from the rice-growing field (Khon Kaen, Thailand) (loamy sand with $\mathrm{pH} 6.04, \mathrm{EC}=0.040 \mathrm{dS} \mathrm{m}^{-1}$, organic matter $=0.235 \%$, total $\mathrm{N}=0.023 \mathrm{mg} \mathrm{kg}^{-1}$, total $\mathrm{P}=36.65 \mathrm{mg} \mathrm{kg}^{-1}$, and total $\mathrm{K}=234.50 \mathrm{mg} \mathrm{kg}^{-1}$ ) and allowed to grow in greenhouse at Department of Biology, Faculty of Science, Khon Kaen University, Thailand for 21 days under natural light ( $11 / 13$ of day $/$ night $)$, temperature $\left(37^{\circ} \mathrm{C}\right.$ of average) and humidity (63\% of average) conditions during February 2018 . For control and drought groups, twenty-oneday old seedlings were foliar-sprayed with $200 \mathrm{ml}$ per pot of acidified water. For chitosan treatements, plants were foliar-sprayed to runoff by a manual sprayer with $200 \mathrm{ml}$ per pot of $50 \mathrm{mgl}^{-1}$ chitosan solution two times ( 9 a.m. and 10 a.m.) at day 14 and 21 after planting. Control group was watered daily to field capacity $(500 \mathrm{ml}$ per pot), meanwhile drought group and three groups of chitosan treatments was imposed to drought stress by withholding water for four days which rice leaves showed drought stressed symptom as the $\mathrm{O}$ shape of leaf rolling (International Rice Research Institute, 2002).

\section{Growth parameter measurement}

Rice seedlings were randomly selected from each pot and gently uprooted. The seedlings were separately measured for shoot and root lengths as well as shoot and root fresh weights. Dry shoot and root weights were obtained after oven-dry at $70^{\circ} \mathrm{C}$ for $72 \mathrm{~h}$. 


\section{Relative water content determination}

Middle leaf blade was cut to piece in the size of $1.5 \times 1.5 \mathrm{~cm}^{2}$, immediately weighed the fresh weight (FW). The leaf piece was then soaked in deionized water for $4 \mathrm{~h}$ under fluorescent light and weighed as turgid weight (TW). It was subsequently dried at $70{ }^{\circ} \mathrm{C}$ for $48 \mathrm{~h}$ and weighed as dry weight (DW). RWC=[(FWDW) $/($ TW-DW $)] \times 100$ (Turner,1981).

\section{Chlorophyll content determination}

Approximately 20-30 mg of leaf tissue was immersed in $80 \%$ acetone for $24 \mathrm{~h}$. Chlorophyll content was spectrophotomically determined at wavelength of 645 and $663 \mathrm{~nm}$ and calculated according to Arnon (1949).

\section{Total soluble sugar and starch extraction and analyses}

Approximately $50 \mathrm{mg}$ of leaf tissue was used for total soluble sugar and starch analyses. Soluble sugars were extracted from the tissues in hot $80 \%(\mathrm{v} / \mathrm{v})$ ethanol three times in a $65^{\circ} \mathrm{C}$ water bath for 60 min each. Total sugar in leaf tissue was determined colorimetrically using phenol sulfuric acid method (Dubois et al., 1956). The leaf residue remaining after ethanolic extraction was hydrolyzed in $1 \mathrm{ml}$ of $0.2 \mathrm{M} \mathrm{KOH}$ and boiled for $30 \mathrm{~min}$. Samples were cooled and adjusted to about pH 5.5 by adding $2 \mathrm{ml}$ of $1 \mathrm{M}$ acetic acid. Starch in the leaf residue was digested with amyloglucosidase overnight, and released glucose was quantified enzymatically using hexokinase/glucose-6-P dehydrogenase.

\section{Electrolyte leakage measurement}

Leaf pieces about 50-60 mg were immersed in $10 \mathrm{ml}$ deionized water for $24 \mathrm{~h}$. Electrical conductivity (EC) was measured by conductivity meter and recorded as EC1. The leaf tissue was then boiled at $100{ }^{\circ} \mathrm{C}$ for $20 \mathrm{~min}$ and cooled down at room temperature. EC was measured and recorded as EC2. The electrolyte leakage was calculated according to Baninasab and Ghobadi (2011).

\section{Malondialdehyde determination}

The production of MDA was estimated base on thiobarbituric acid (TBA) reactivity. Leaf samples were ground thoroughly with $2 \mathrm{ml}$ of $0.1 \%(\mathrm{w} / \mathrm{v})$ trichloroacetic acid, followed by centrifugation at $1000 \mathrm{rpm}$ for 5 min. A mixture of $0.5 \mathrm{ml}$ of supernatant and $1.5 \mathrm{ml}$ of $0.5 \% \mathrm{TBA}$ was boiled in a $95^{\circ} \mathrm{C}$ water bath for $30 \mathrm{~min}$. The reaction was stopped by freezing on ice for $10 \mathrm{~min}$. The absorbance was determined at wavelength of 532 $\mathrm{nm}$. The concentration of TBA reacting substance (TBARS) was calculated using a molar extinction coefficient of $155 \mathrm{mM}^{-1} \mathrm{~cm}^{-1}$ (Sunohara and Matsumoto, 2004).

\section{$\mathrm{H}_{2} \mathrm{O}_{2}$ determination}

Leaf samples were ground thoroughly with $1 \mathrm{ml}$ of $0.1 \%(\mathrm{w} / \mathrm{v})$ trichloroacetic acid, followed by 1500 $\mathrm{rpm}$ centrifugation at $4^{\circ} \mathrm{C}$ for $15 \mathrm{~min}$. The reaction mixture was prepared by mixing $0.5 \mathrm{ml}$ of supernatant, 0.5 $\mathrm{ml}$ of $10 \mathrm{mM}$ potassium phosphate buffer, and $1 \mathrm{M}$ of KI and spectrophotomically measured at a wavelength of $390 \mathrm{~nm}$ (Terzi et al., 2014).

\section{Antioxidant enzyme activity assay}

Approximately $0.05 \mathrm{~g}$ of leaf sample was thoroughly ground on ice using mortar and pestle in $4 \mathrm{ml}$ of extraction buffer [ $50 \mathrm{mM}$ potassium phosphate buffer ( $\mathrm{pH}$ 7.8), $0.4 \mathrm{mM}$ EDTA, $1 \mathrm{mM}$ ascorbic acid and 2\% polyvinyl polypyrrolidone]. The extract was filtered through 4 layers of cheesecloth, then centrifuged at 10,000 $\mathrm{rpm}$ for $1 \mathrm{~min}$. The filtrate was then used as an enzyme extract for superoxide dismutase (SOD; EC 1.15.1.1), catalase (CAT; EC 1.11.1.6), ascorbate peroxidase (APX; EC 1.11.1.11) and guaiacol peroxidase (GPX, EC 1.11.1.7) assays (Lu et al., 2009). The amount of protein in the enzyme extract was determined by the Bradford method (Bradford, 1976). 
SOD activity was assayed by measuring its ability to inhibit the photochemical reduction of NBT. The reaction mixture $(2 \mathrm{ml})$ contained $50 \mathrm{mM}$ potassium phosphate buffer $(\mathrm{pH} 7.8), 10 \mathrm{mM}$ methionine, $50 \mu \mathrm{M}$ NBT, $0.025 \%$ Triton X-100 and $10 \mu \mathrm{M}$ riboflavin. The photo-reduction of NBT was measured at $560 \mathrm{nM}$. One unit of SOD was defined as the amount of enzyme that produced $50 \%$ inhibition of NBT. CAT activity was assayed in a $2 \mathrm{ml}$ reaction mixture containing $50 \mathrm{mM}$ potassium phosphate buffer $(\mathrm{pH} 7.0), 25 \mathrm{mM} \mathrm{H}_{2} \mathrm{O}_{2}$, and $0.1 \mathrm{ml}$ of enzyme extract. The subsequence decomposition of $\mathrm{H}_{2} \mathrm{O}_{2}$ was observed at $240 \mathrm{~nm}(\mathrm{E}=0.0394$ $\left.\mathrm{mM}^{-1} \mathrm{~cm}^{-1}\right)$. APX activity was assayed in a $2 \mathrm{ml}$ reaction mixture containing $50 \mathrm{mM}$ potassium phosphate buffer ( $\mathrm{pH} 7.0), 1 \mathrm{mM}$ ascorbic acid, $0.4 \mathrm{mM}$ EDTA, $12.5 \mathrm{mM} \mathrm{H}_{2} \mathrm{O}_{2}$ and $0.1 \mathrm{ml}$ of enzyme extract. The subsequent decrease in ascorbic acid was observed at $290 \mathrm{~nm}\left(\mathrm{E}=2.8 \mathrm{mM}^{-1} \mathrm{~cm}^{-1}\right)$ (Sunohara and Matsumoto, 2004). GPX activity was assayed in a $2 \mathrm{ml}$ reaction mixture containing $50 \mathrm{mM}$ potassium phosphate buffer, $3 \%$ guaiacol, 20 $\mathrm{mM} \mathrm{H}_{2} \mathrm{O}_{2}$, and $0.1 \mathrm{ml}$ of enzyme extract. GPX activity was calculated from the formation of tetraguaiacol per minute at $470 \mathrm{~nm}\left(\mathrm{E}=26.6 \mathrm{mM}^{-1} \mathrm{~cm}^{-1}\right)($ Uarrota et al., 2016).

\section{Statistical analysis}

The experiment was designed as a completely randomized design with four replicates. Data were analyzed by one-way analysis of variance (One-way ANOVA) using SPSS version 24 (IBM Corp., Armonk, N.Y., USA). The mean differences were compared by Duncan's multiple range comparison test. $P$-values $<0.05$ were considered significantly different. Data were expressed as means \pm standard errors.

\section{Results}

\section{Chitosan pretreatment enhanced rice seedling growth under drought stress}

Drought stress resulted in the overall reduction of shoot and root growths of rice seedling as indicated by the decreases in shoot length, root length, shoot and root fresh weights as well as shoot and root dry weights (Figure 1A-F). Although exogenous chitosan application had little effect on shoot growth (Figure 1A, 1C, 1E), its application promoted root growth in rice seedling as seen by the increases of root fresh and dry weight (Figure 1D, 1F). Low MW chitosan was the most effective in promoting root growth, followed by medium MW and high MW chitosan, respectively (Figure 1B, 1D, 1F).

\section{Effects of chitosan on some physiological characteristics of rice plant under drought stress}

The relative water content of leaf was significantly reduced when the plant was subjected to drought stress. All chitosan treatments caused a significant increase in relative water content compared to the untreated plants (Figure 2A). Additionally, drought stress resulted in increases of electrolyte leakage as well as MDA in the leaf. All chitosan treatments showed a reduction in electrolyte leakage and MDA (Figure 2B, 2C). The electrolyte leakage and MDA of all chitosan treatments were similar to those of the control plants, and there was no difference between each chitosan treatment. $\mathrm{H}_{2} \mathrm{O}_{2}$ significantly increased when the plant was subjected to drought. Treating with three different MW of chitosans resulted in a lower concentration of $\mathrm{H}_{2} \mathrm{O}_{2}$ in which the high MW chitosan had a significant lowest $\mathrm{H}_{2} \mathrm{O}_{2}$ among the treated groups (Figure 2D).

Drought stress also caused reductions in both total soluble sugar and starch content in leaf. Treating with chitosans, however, significantly increases the accumulation of total soluble sugar and starch in the leaf (Figure 2E, 2F). Also, low MW chitosan caused the highest increase in starch level in the leaf, followed by medium and high MW chitosan, respectively (Figure $2 \mathrm{~F}$ ). 

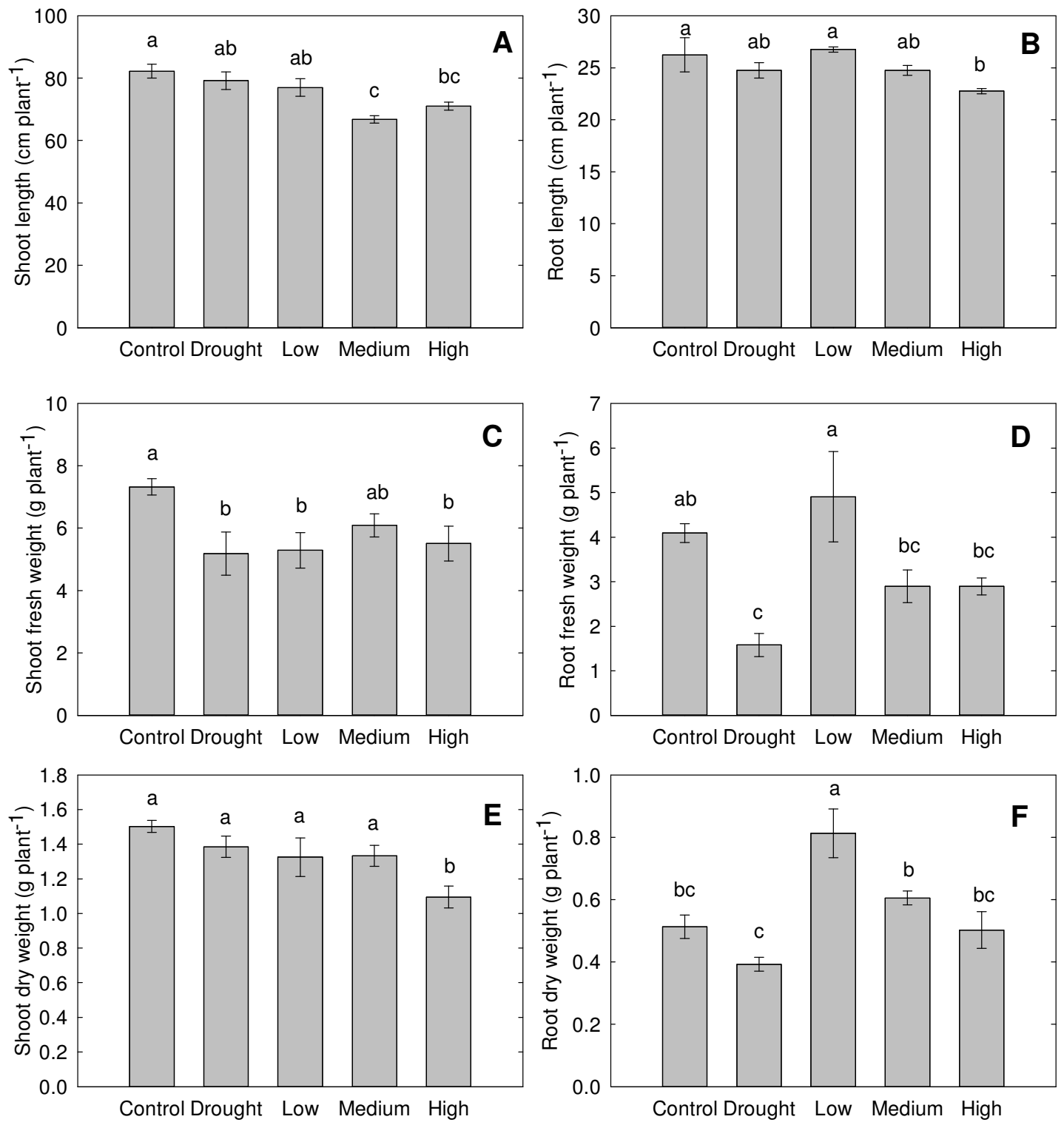

Figure 1. Effects of chitosan pretreatment shoot length (A), root length (B), shoot fresh weight (C), root fresh weight $(\mathrm{D})$, shoot dry weight $(\mathrm{E})$ and root dry weight $(\mathrm{F})$ of rice seedling under drought stress Values are expressed as mean \pm S.E. $(n=4)$. Different letter indicates significant difference $(P<0.05)$ by Duncan's multiple range comparison test 

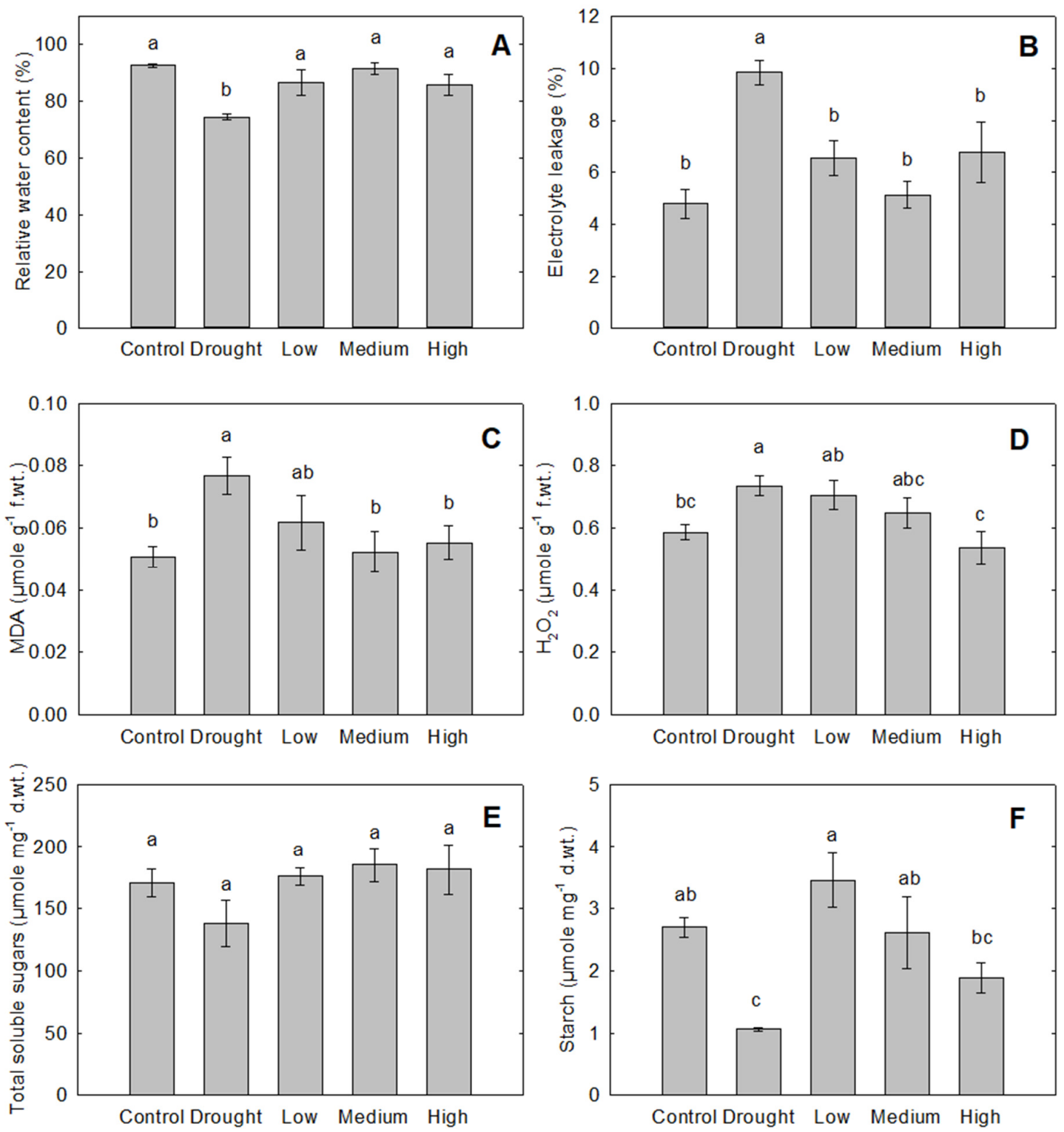

Figure 2. Effects of chitosan pretreatment on relative water content (A), electrolyte leakage (B), MDA (C), $\mathrm{H}_{2} \mathrm{O}_{2}(D)$, total soluble sugar $(\mathrm{E})$, and starch $(\mathrm{F})$ in rice seedling under drought stress

Values are expressed as mean \pm S.E. $(n=4)$. Different letter indicates significant difference $(P<0.05)$ by Duncan's multiple range comparison test

\section{Chitosan pretreatment improves chlorophyll content in rice seedling under drought condition}

The results showed that drought stress negatively affected chlorophyll $a$, chlorophyll $b$, and total chlorophyll content in the leaf of rice seedling. Treating with low, medium, and high MW chitosans resulted in a significantly higher concentration of chlorophyll a compared to the droughted plant (Figure 3A). Chitosan treatments also increase chlorophyll $b$ concentration compared to the untreated plant in which high $\mathrm{MW}$ chitosan caused the highest increase in chlorophyll $b$ concentration, followed by medium MW and low MW chitosan, respectively (Figure 3B). In addition, leaf total chlorophyll content was highest in the high MW chitosan group compared to other chitosan treatments and the droughted plant; however, the values are not significantly different within the chitosan treatments (Figure 3C). 

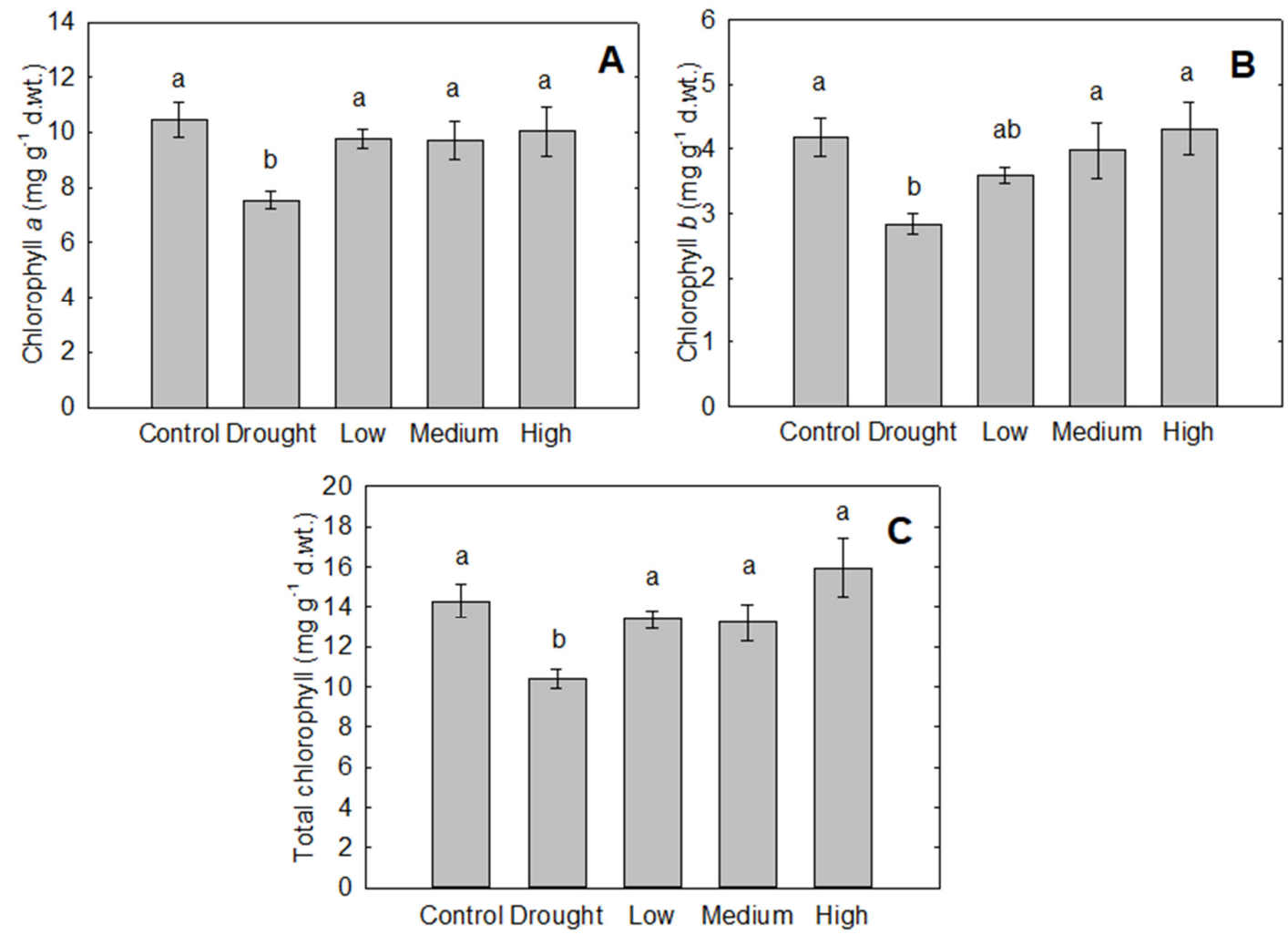

Figure 3. Effects of chitosan pretreatment on chlorophyll $a(\mathrm{~A})$, chlorophyll $b(\mathrm{~B})$, and total chlorophyll (C) contents in rice seedling under drought stress

Values are expressed as mean \pm S.E. $(n=4)$. Different letter indicates significant difference $(P<0.05)$ by Duncan's multiple range comparison test

\section{Chitosan application elicited $R O S$ scavenging system}

The activities of antioxidant enzymes, including SOD, CAT, APX, and GPX increased slightly when the plant was subjected to drought stress. Treating with medium MW chitosan resulted in the highest activity of SOD, followed by high MW and low MW chitosan, respectively (Figure 4A). Their activities, however, were not significantly different compared to the untreated group. Similarly, treating with all type of chitosans also increase the activity of CAT in which low MW chitosan resulted in the highest CAT activity, followed by high MW and medium MW, respectively (Figure 4B). The activity of APX also increased when the plant was treated with all type of chitosans, and their activities were not significantly different (Figure 4C). Besides, low MW and high MW chitosans caused a significant increase in GPX activity compared to the untreated plant; however, its activity in the medium MW group was not different from the untreated plant (Figure 4D). 

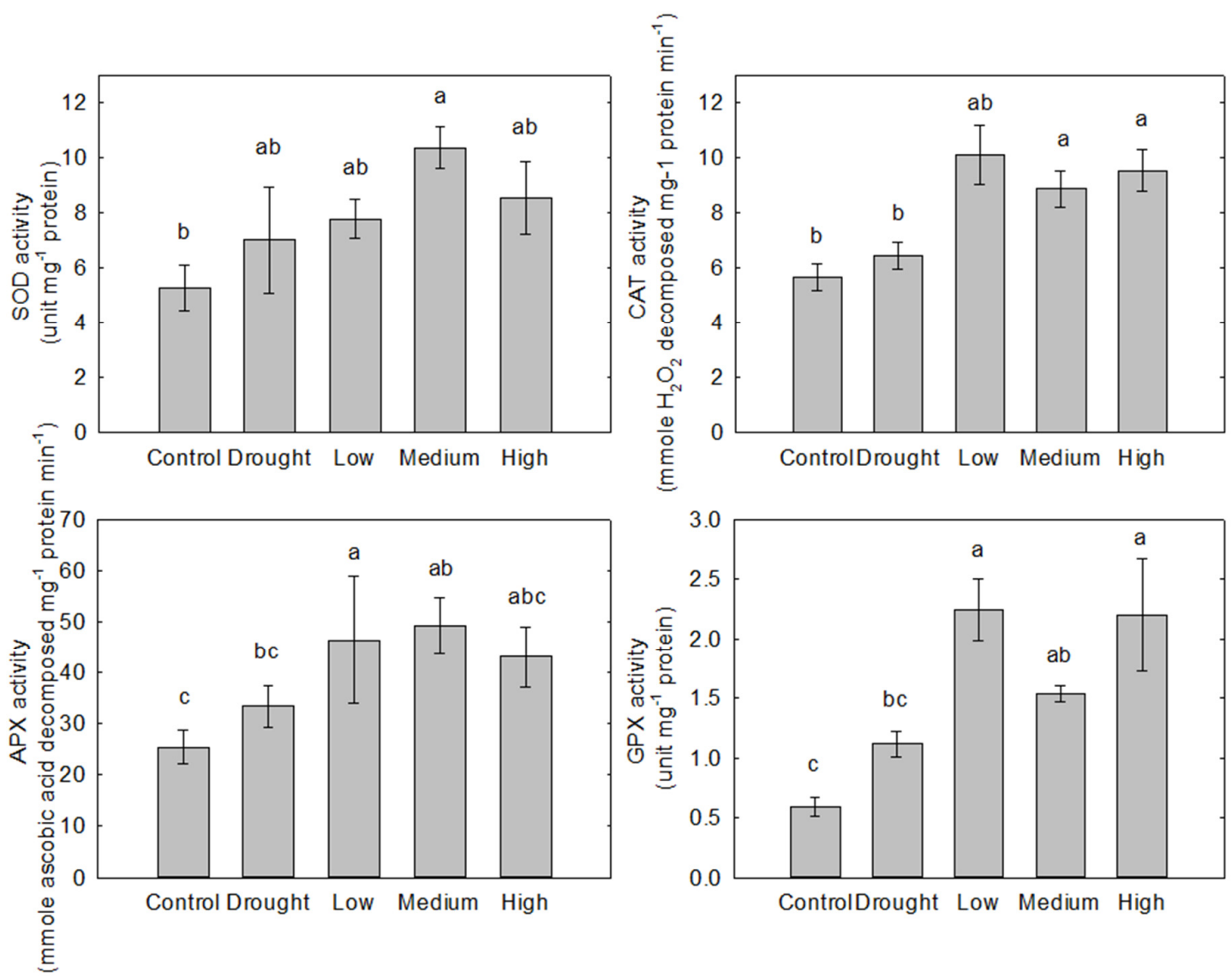

Figure 4. Effects of chitosan pretreatment on SOD (A), CAT (B), APX (C), and GPX (D) activities in rice seedling under drought stress. Values are expressed as mean \pm S.E. $(n=4)$

Different letter indicates significant difference $(P<0.05)$ by Duncan's multiple range comparison test

\section{Discussion}

The effectiveness of chitosan on increase plant growth has been reported in various plants. Foliar spray with different type and deacetylation degree of chitosan promoted the growth of 'Leung Pra Tew 123' rice seedlings under normal condition via induction of many growth-related genes, and the best enhancement was observed in rice seedlings treated with oligomeric chitosan (Chamnanmanoontham, 2015). The present study revealed that chitosan enhanced rice seedling growth by increase root fresh and dry weights, especially treating with low MW chitosan. Ma et al. (2014) also reported that chitosan promotes wheat growth in terms of germination capacity, root length, and increase in root activity. Increased root growth strengthens the capacity of water absorption, therefore, enhance drought resistance of the seedlings (Katiyar et al., 2015). Drought stress also has a negative effect on relative water content as well as membrane stability and integrity as indicated by increases of electrolyte leakage and MDA. These effects, however, are alleviated when the plant was pretreated with chitosan. The previous research also indicated that using chitosan nanoparticle through the soil and foliar application significantly increased relative water content in barley (Hordeum vulgare L.) under late-season drought stress (Behboudi et al., 2018). It is also shown that chitosan application increased cell membrane permeability and decreased MDA content in Thymus daenensis as well as wheat under drought stress (Rebolledo et al., 2012; Zeng and Luo, 2012). 
Photosynthetic pigments are also considerably reduced by drought stress. This effect also leads to the reduction of total soluble sugar and starch accumulation in the leaf. Treating with chitosan helps the plant to maintain photosynthetic function as indicated by higher concentration of chlorophyll $a$, chlorophyll $b$, and total chlorophyll under drought stress. Sugar and starch accumulations are also observed in the chitosan-treated plant exposed to drought stress. In basil and white cover plants, chitosan application significantly increased soluble sugar content under severe drought (Pirbalouti et al., 2017). Besides providing energy, sugars play a crucial role in downstream events of gene expression and signal transduction of a wide range of abiotic stresses. Sugar accumulation has been known to play an essential role in an osmotic adjustment under drought condition (Wu et al., 2016). Sugar metabolism is also involved in membrane stabilization, conferring plant resistance against drought stress (Gupta and Thind, 2019). Treating with low MW chitosan also leads to the highest starch accumulation, compared to the other chitosan treatments as well as the untreated plant. Starch accumulation during the drought period is believed to be a key component of drought tolerance mechanism (Dong and Beckles, 2019).

Generally, drought stress generates the excessive ROS which damages plants by oxidizing photosynthetic pigments, membrane lipids, proteins, and nucleic acids (Yordanov et al., 2000). In this study, $\mathrm{H}_{2} \mathrm{O}_{2}$ significantly increased in response to drought stress. Plants normally cope with oxidative damage by increasing the activity of antioxidant enzymes in which indicates drought resistance in plants (Weng et al., 2015). The present study demonstrated that chitosan pretreatment induces the activities of SOD, CAT, APX as well as GPX. It was also reported that chitosan alleviates the adverse effect of water stress by enhanced production of antioxidant enzymes (Hidangmayum et al., 2019). The result also corresponded to the previous studies, which also revealed that chitosan application increases APX in rice cv. 'LPT123-TC171', as well as SOD, POX, and CAT activities in wheat under drought stress (Zeng and Luo, 2012; Pongprayoon et al., 2013). Also, application of chitosan at low concentrations increased antioxidant enzyme, including CAT and POX, activities in wheat and maize seedlings under salt stress condition; however, the activities are reduced at higher concentrations of chitosan (Peykani and Sepehr, 2018).

\section{Conclusions}

The results obviously suggested that chitosan pretreatment through the method of seed priming combined with foliar spray could alleviate the effect of drought stress in the rice seedlings. Chitosan, especially low MW, enhances root growth which may increase water absorption. Chitosan also helps the plant to maintain water content under drought condition. Photosynthetic capacity is improved, possibly by preventing pigment disintegration. Rice plant treated with chitosan displays a better osmotic adjustment via accumulation

of sugar as well as starch, especially those treated with low MW chitosan. In addition, chitosan reduced the severity of drought by improving membrane stability and integrity corresponded with the increase in antioxidant enzyme activity.

\section{Authors' Contributions}

Both authors read and approved the final manuscript. 


\section{Acknowledgements}

This work was supported by Science Achievement Scholarship of Thailand (SAST) and Salt Tolerant Rice Research Group (STRG), Department of Biology, Faculty of Science, Khon Kaen University, Thailand.

\section{Conflict of Interests}

The authors declare that there are no conflicts of interest related to this article.

\section{References}

Arnon DI (1949). Copper enzymes in isolated chloroplasts. Polyphenoloxidase in Beta vulgaris. Plant Physiology 24(1):115. https://doi.org/10.1104/pp.24.1.1

Baninasab B, Ghobadi C (2011). Influence of paclobutrazol and application methods on high temperature stress injury in cucumber seedling. Journal of Plant Growth Regulation 30:213-219. https://doi.org/10.1007/s00344-010-91882

Behboudi F, Sarvestani TT, Kassaee ZZ, Sanavi MM, Sorooshzadeh S, Ahmadi AB (2018). Evaluation of chitosan nanoparticles effects on yield and yield components of barley (Hordeum vulgare L.) under late season drought stress. Journal of Water and Environmental Nanotechnology 3(1):22-39. https://dx.doi.org/10.22090/jwent.2018.01.003

Bradford MM (1976). A rapid and sensitive method for the quantitation of microgram quantities of protein utilizing the principle of protein-dye binding. Analytical Biochemistry 72:248-254. https://doi.org/10.1016/00032697(76)90527-3

Chamnanmanoontham N, Pongprayoon W, Pichayangkura R, Roytrakul S, Chadchawan S (2015). Chitosan enhances rice seedling growth via gene expression network between nucleus and chloroplast. Plant Growth Regulation 75:101-114. https://doi.org/10.1007/s10725-014-9935-7

Dong S, Beckles DM (2019). Dynamic changes in the starch-sugar interconversion within plant source and sink tissues promote a better abiotic stress response. Journal of Plant Physiology 245:80-93. https://doi.org/10.1016/j.jplph.2019.01.007

Du Jardin P (2015). Plant biostimulants: definition, concept, main categories and regulation. Scientia Horticulturae 196:3-14. https://dx.doi.org/10.1016/j.scienta.2015.09.021

Dubois M, Gilles KA, Hamilton JK, Rebers PA, Smith F (1956). Colorimetric method for determination of sugars and related substances. Analytical Chemistry 28:350-356. https://doi.org/10.1021/ac60111a017

Fang Y, Xiong L (2015). General mechanisms of drought response and their application in drought resistance improvement in plants. Cellular and Molecular Life Sciences 72:673-689. https://doi.org/10.1007/s00018-0141767-0

Gupta N, Thind SK (2019). Foliar application of glycine betaine alters sugar metabolism of wheat leaves under prolonged field drought stress. Proceedings of the National Academy of Sciences, India Section B: Biological Sciences 89:877884. https://doi.org/10.1007/s40011-018-1000-2

Hidangmayum A, Dwivedi P, Katiyar D, Hemantaranjan A (2019). Application of chitosan on plant responses with special reference to abiotic stress. Physiology and Molecular Biology of Plants 25:313-326. https://doi.org/10.1007/s12298-018-0633-1

International Rice Research Institute (2002). Rice-Standard-Evaluation-System_2002. Retrieved 2018 January 15 from http://www.knowledgebank.irri.org/images/docs/rice-standard-evaluation-system.pdf

Katiyar D, Hemantaranjan A, Singh B (2015). Chitosan as a promising natural compound to enhance potential physiological response in plant: a review. Indian Journal of Plant Physiology 20:1-9. https://doi.org/10.1007/s40502-015-0139-6

Lian-Ju M, Yue-Ying L, Lan-Lan W, Xue-Mei L, Liu T, Bu N (2014). Germination and physiological response of wheat (Triticum aestivum) to pre-soaking with oligochitosan. International Journal of Agriculture and Biology 16:766770 . 
Lin W, Hu X, Zhang W, Rogers WJ, Cai W (2005). Hydrogen peroxide mediates defense responses induced by chitosans of different molecular weights in rice. Journal of Plant Physiology 162:937-944. https://doi.org/10.1016/j.jplph.2004.10.003

Lizárraga-Paulín EV, Torres-Pacheco I, Moreno-Martínez E, Miranda-Castro SP (2011). Chitosan application in maize (Zea mays) to counteract the effects of abiotic stress at seedling level. African Journal of Biotechnology 10(34):6439-6446. https://www.ajol.info/index.php/ajb/article/view/94630

$\mathrm{Lu} \mathrm{S,} \mathrm{Su} \mathrm{W,} \mathrm{Li} \mathrm{H,} \mathrm{Guo} \mathrm{Z} \mathrm{(2009).} \mathrm{Abscisic} \mathrm{acid} \mathrm{improves} \mathrm{drought} \mathrm{tolerance} \mathrm{of} \mathrm{triploid} \mathrm{bermudagrass} \mathrm{and} \mathrm{involves} \mathrm{H}_{2} \mathrm{O}_{2}-$ and NO-induced antioxidant enzyme activities. Plant Physiology and Biochemistry 47:132-138. https://doi.org/10.1016/j.plaphy.2008.10.006

Malerba M, Cerana R (2018). Recent advances of chitosan applications in plants. Polymers 10(2):118-127. https://dx.doi.org/10.3390\%2Fpolym10020118

Peykani LS, Sepehr MF (2018). Effect of chitosan on antioxidant enzyme activity, proline, and malondialdehyde content in Triticum aestivum L. and Zea may L. under salt stress condition. Iranian Journal of Plant Physiology 9:26612670.

Pirbalouti AG, Malekpoor F, Salimi A, Golparvar A (2017). Exogenous application of chitosan on biochemical and physiological characteristics, phenolic content and antioxidant activity of two species of basil (Ocimum ciliatum and Ocimum basilicum) under reduced irrigation. Scientia Horticulturae 217:114-122. https://doi.org/10.1016/j.scienta.2017.01.031

Pongprayoon W, Roytrakul S, Pichayangkrua R, Chadchawan S (2013). The role of hydrogen peroxide in chitosaninduced resistance to osmotic stress in rice (Oryza sativa L.). Plant Growth Regulation 70:159-173 https://doi.org/10.1007/s10725-013-9789-4

Prabnakorn S, Maskey S, Suryadi FX, de Fraiture, C (2018.). Rice yield in response to climate trends and drought index in the Mun River Basin, Thailand. Science of the Total Environment 621:108-119. https://doi.org/10.1016/j.scitotenv.2017.11.136

Prashanth KVH, Tharanathan RN (2007). Chitin/chitosan: modifications and their unlimited application potential- an overview. Trends in Food Science \& Technology 18:117-131. https://doi.org/10.1016/j.tifs.2006.10.022

Rajoka MSR, Zhao L, Mehwish HM, Wu Y, Mahmood S (2019). Chitosan and its derivatives: synthesis, biotechnological applications, and future challenges. Applied Microbiology and Biotechnology 103:1557-1571. https://doi.org/10.1007/s00253-018-9550-Z

Rebolledo M, Dingkuhn M, Clement-Vidal A, Rouan L, Luquet D (2012). Phenomics of rice early vigour and drought response: Are sugar related and morphogenetic traits relevant. Rice 5:2-15. https://doi.org/10.1186/1939-8433$5-22$

Rinaudo M (2006). Chitin and chitosan: Properties and applications. Progress in Polymer Science 31(7):603-632. https://doi.org/10.1016/j.progpolymsci.2006.06.001

Seang-Ngam S, Limruengroj K, Pichyangkura R, Chadchawan S, Buaboocha T (2014). Chitosan potentially induces drought resistance in rice Oryza sativa L. via calmodulin. Journal of Chitin and Chitosan Science 2(2):117-122. https://doi.org/10.1166/jcc.2014.1060

Sharma HSS, Fleming C, Selby C, Rao JR, Martin T (2014). Plant biostimulants: a review on the processing of macroalgae and use of extracts for crop management to reduce abiotic and biotic stresses. Journal of Applied Phycology 26:465490. https://doi.org/10.1007/s10811-013-0101-9

Sunohara Y, Matsumoto H (2004). Oxidative injury induced by the herbicide quinclorac on Echinochloa oryzicola Vasing. And the involvement of antioxidant ability in its highly selective action in grass species. Plant Science 167:597-606. https://doi.org/10.1016/j.plantsci.2004.05.005

Terzi R, Kadioglu A, Kalaycioglu E, Saglam A (2014). Hydrogen peroxide pretreatment induces osmotic stress tolerance by influencing osmolyte and abscisic acid levels in maize leaves. Plant-Environment Interactions 9(1):559-565. https://doi.org/10.1080/17429145.2013.871077

Toldi O, Tuba Z, Scott P (2009). Vegetative desiccation tolerance: is it a gold mind for bioengineering crops? Plant Science176:187-199. https://doi.org/10.1016/j.plantsci.2008.10.002

Turner NC (1981). Techniques and experimental approaches for the measurement of plant water status. Plant Soil 58:339-366. https://doi.org/10.1007/BF02180062

Uarrota VG, Moresco R, Schmidt EC, Bouzon ZL, Nunes EC, Neubert EO, ... Maraschin M (2016). The role of ascorbate peroxidase, guaiacol peroxidase, and polysaccharides in cassava (Manihot esculenta Crantz) roots under 
Moolphuerk N and Pattanagul W (2020). Not Bot Horti Agrobo 48(4):2072-2084

$\begin{array}{llll}\text { postharvest physiological } & \text { feterioration. } & \text { Food }\end{array}$ https://doi.org/10.1016/j.foodchem.2015.11.025

Weng M, Cui L, Liu F, Zhang M, Shan L, Yang S, Deng XP (2015). Effects of Drought Stress on Antioxidant Enzymes in Seedlings of Different Wheat Genotypes. Pakistan Journal of Botany 47(1):49-56.

Wu GQ, Feng RJ, Shui QZ (2016). Effect of osmotic stress on growth and osmolytes accumulation in sugar beet (Beta vulgaris L.) plants. Plant, Soil and Environment 62(4):189-194. https://doi.org/10.17221/101/2016-PSE

Yang F, Hu J, Li J, Wu X, Qian Y (2009). Chitosan enhances leaf membrane stability and antioxidant enzyme activities in apple seedlings under drought stress. Plant Growth Regulation 58(2):131-136. https://doi.org/10.1007/s10725-009-9361-4

Yordanov I, Velikova V, Tsonev T (2012). Plant responses to drought, acclimation, and stress tolerance. Photosynthetica 38:171-186. https://doi.org/10.1023/A:1007201411474

Yoshihashi T, Nguyen TTH, Kabaki N (2004). Area dependency of 2-acetyl-1-pyrroline content in an aromatic rice variety, Khao Dawk Mali 105. Japan Agricultural Research Quarterly 38:105-109. https://doi.org/10.6090/jarq.38.105

Zeng D, Luo X (2012). Physiological effects of chitosan coating on wheat growth and activities of protective enzyme with drought tolerance. Open Journal of Soil Science 2(3):282-288. http://dx.doi.org/10.4236/ojss.2012.23034


The journal offers free, immediate, and unrestricted access to peer-reviewed research and scholarly work. Users are allowed to read, download, copy, distribute, print, search, or link to the full texts of the articles, or use them for any other lawful purpose, without asking prior permission from the publisher or the author.

License - Articles published in Notulae Botanicae Horti Agrobotanici Cluj-Napoca are Open-Access, distributed under the terms and conditions of the Creative Commons Attribution (CC BY 4.0) License. (c) Articles by the authors; UASVM, Cluj-Napoca, Romania. The journal allows the author(s) to hold the copyright/to retain publishing rights without restriction. 